SOI: 1.1 /TAS DOI: $10.15863 / \mathrm{TAS}$

\section{International Scientific Journal} Theoretical \& Applied Science

p-ISSN: 2308-4944 (print) ｅ-ISSN: 2409-0085 (online)

Year: 2015 Issue: 07 Volume: 27

Published: $30.07 .2015 \quad$ http://T-Science.org
Gulchexra Rustamovna Raxmatkariyeva

doctoral candidate-researcher of

State institute of arts and culture of Uzbekistan,

Uzbekistan

grahmatkarieva@gmail.com

SECTION 16. Music. Cinema art. Theatre.

\title{
TO DISCUSSION OF A QUESTION OF IDENTIFICATION OF TELEVISION
}

\begin{abstract}
The article is devoted to the issues of television identification which are considered from various areas of activity to which it belongs (creative, professional and production). Other issues raised are concerned with the specifics of the small screen which possess own rules, means of expression and functioning trends as well as its own place in Art and Journalism. The article also sheds light on necessity of comprehension of complex nature of television and understanding of multi-factor nature of TV practice and connected concepts

Key words: Identification of TV, the specifics of the small screen, history of television, theory of $T V$, practice of TV, TV journalism, systems approach, program activities, the synthetic nature of television, TV products, communication, entertainment, versatility, the uniqueness of the TV.

Language: Russian

Citation: Raxmatkariyeva GR (2015) TO DISCUSSION OF A QUESTION OF IDENTIFICATION OF TELEVISION. ISJ Theoretical \& Applied Science 07 (27): 143-146.

Soi: http://s-o-i.org/1.1/TAS-07-27-25 Doi: crossef http://dx.doi.org/10.15863/TAS.2015.07.27.25
\end{abstract}

\section{К ОБСУЖДЕНИЮ ВОПРОСА ОБ ИДЕНТИФИКАЦИИ ТЕЛЕВИДЕНИЯ}

Аннотация: В настоящчей статье освещзаются вопросы идентификации телевидения с точки зрения того, к какой сфере деятельности (творческой, профессиональной и производственной) оно относится. Здесь также речь идет о специфике малого экрана, которому присущи свои правила, средства выражения, закономерности функиионирования и свое место в структуре искусства и журналистики, о необходимости понимания многосложной природы ТВ и осознания многофакторности телевизионной практики и связанных с ней аспектов.

Ключевые слова: Идентификация телевидения, специфика малого экрана, история телевидения, теория телевидения, практика телевидения, тележурналистика, системный подход, синкрез, программная деятельность, синтетическая природа ТВ, телепродукиия, коммуникация, зрелищность, универсальность, уникальность телевидения.

На вопросы о том, что такое телевидение и к какой сфере деятельности (творческой, производственной или другой) оно относится, пытались и пытаются ныне ответить и историки, и теоретики и практики ТВ. Однако, ввиду многозначности и динамичности этой сложнейшей организации, представляющей интересы различных смежных, соприкасающихся, пересекающихся и параллельных структур (искусства, культуры в целом, журналистики, техники), ответы, удовлетворяющие хотя бы одну из сторон этого процесса, следует искать в трудах по истории телевидения, в числе которых «Очерки истории телевидения» Э.Багирова [1]; «Краткий очерк становления и развития отечественного и зарубежного телевидения» Н.Голядкина [6]; «Три этапа новейшей истории телевизионной журналистики (1985-1998)» В.Гаспарян [5], где автор наблюдает перестроечную, постперестроечную практику телевидения, пережившего в 90-е годы XX века идейнотворческое обновление, осознание себя как важнейшего звена социально-культурных реформ.

О телевидении как составной части обширной художественной сферы пишут В.Михалкович («О сущности телевидения») [10], Б. Сапунов («Телевидение и культура») [18]. 
Ю.Борев, А.Вартанов, Б.Галеев, В.Кондратов, Дж. Фиск, Е.Чичина, Н.Шеляпин рассматривают ТВ как вид искусства, в котором эстетические качества органически сочетаются с техническими. В отдельных случаях ТВ причисляют к продукции «малоэкранного кино» или же видят кино в контексте малого экрана.

Если в искусствоведческих работах телевидение видится в одном ряду (по линии природных, эстетических свойств, восприятия коммуникативных характеристик, технологий) с основными (традиционными) видами искусства, то в журналистиковедческих - его относят к журналистике (наряду с журнально-газетной и радийной), или же исключительно к тележурналистике, отказывая ему в самостоятельности как искусства, которое прошло собственный путь развития со своими художественными закономерностями, приоритетами и ценностями, сформировало творческую и производственную базу.

Различные аспекты функционирования телевидения в современных условиях представлены в отдельных публикациях по теории журналистики и массовых коммуникаций. В частности, Я.Засурский в своей работе «Средства массовой информации в информационном обществе» [7] делит журналистику переходного периода на отдельные этапы, выявляя ее специфические особенности, принципы взаимодействия с другими социальными институтами.

Свойства журналистики освещаются в работах В.Перевалова «Культуроформирующие функции, состав, структура и место в системе функций журналистики» [15], Е.Прохорова «Введение в теорию журналистики» [16].

В диссертации С.Уразовой «Телевидение как институциональная система отражения социокультурных потребностей» [20] осмысливается в контексте социального развития в динамике и взаимосвязи разнообразных факторов общественной жизни и сфер человеческого созидания, с учетом эстетических, духовных приоритетов современности. Автор анализирует деятельность ТВ согласно пяти общепризнанным

(технологическое, профессиональное, направлениям экономическое, пространственное, культурное), которые объединены общими задачами производства аудиовизуальной продукции, поиска новых форм и жанров, креативизации организационно-творческого процесса.

Анализу состояния современного телевидения, открывшего новые формы вещания, посвящены книги С.Муратова «Телевидение в поисках телевидения» [12], «Телевизионное общение в кадре и за кадром» [13]. Монография режиссера кино и телевидения, педагога и теоретика А.Соколова «Природа экранного творчества» [19] содержит несколько важных теоретических положений, касающихся методологии телевизионного творчества.

$$
\text { С теорией телевидения связаны }
$$

фундаментальные труды И.Беляева, Р. Борецкого, М. Волынца, О. Дворниченко, Н. Горюновой, В.Егорова, Н. Ефимовой, Р.Ильина, С.Муратова, Н.Приваловой, В.Саппак, Н.Утиловой, С.Новаковского, С.Шумиловой, в которых освещаются вопросы освоения телеэкраном образного языка, специфики осуществления информационно-публицистических,

художественно-развлекательных, аналитических программ.

В.Ю.Борев и А.В.Коваленко видят в телевидении искусство и журналистику одновременно [3]. Г.В.Кузнецов В.Л.Цвик, А.Я.Юровский [8], говорят о его публицистичности, художественности и научности, т. е. многослойности ТВ и необходимости системного подхода к его осмыслению, на чем настаивали в свое время Ю.П.Буданцев [4], О.Ф.Нечай [14], К.Разлогов [17] и что соответствовало представлениям М.Маклюэна [9], А.Моля [11], Р.Уильямса [20] о мозаичности, многоступенчатости данного явления.

В рамках культурологии ТВ понимается как синкрез (нерасчлененное единство) различных видов деятельности: производящей и презентующей, социально-творческой, журналистской. М.М.Бахтин в свою очередь отмечает родство телеэкрана с карнавальным мироощущением [2], которое заложено в природе зрелища и типе коммуникации - игровой, драматической, театральной. В пользу зрелищности телевидения говорит также использование им разнообразного художественно-образного арсенала театрального, кинематографического, музыкального, изобразительного искусства, а также архитектуры и дизайна.

Однако ТВ опирается не только на традиционные жанры и наработанный веками богатый журналистский опыт, но и на достижения современной техники и технологии, что является свидетельством универсальности и уникальности телевидения, объединившего под своим началом полномочия печати, радио, аудиовизуального искусства и техники.

Можно говорить также о синтетической природе телевидения, которая проявляется:

- в программной деятельности, неотъемлемой частью которой являются различные виды литературы и искусства;

- в технологии осуществления передач усилиями большой группы людей (авторов, 
редакторов, режиссеров, операторов, звукооператоров, сценографов, композиторов, специалистов по видео и компьютерной технике);

- в новостной и информационноаналитической продукции, состоящей из средств массовой информации и пропаганды, a также телеискусства (наличие драматургии, хроникальных кадров, фотоиллюстрации, музыки, дизайна, монтажа);

- в жанровой природе телевизионных произведений (телефильмы, телеспектакли, репортажи, ток-шоу, интервью и др.), представляющей собой разнообразие творческой деятельности, видов и жанров искусства.

Мобильность, масштабность охвата пространства и времени, скорость отражения текущих событий (новости, трансляции, прямые репортажи), бесперебойность вещания, креативность технических и профессиональных решений - неоспоримые признаки (наряду с другими факторами) самостоятельности телевидения как:

- важнейшей сферы производства и воспроизводства культуры, художественных ценностей, обладающих эстетическим качеством;

- аудиовизуального искусства, сочетающего аудио и зрительные образы;

- средства массовой информации, связанной с журналистской деятельностью;

- продукта современной техногенной цивилизации;

- сложнейшего технологического образования, осуществляющего программы и передачи посредством современных инноваций.

Поэтому можно говорить о специфике малого экрана, которому присущи свои правила, средства выражения, методы, своя поэтика и свое место в структуре художественной культуры, искусства, журналистики, современных технологий. И идентификация ТВ не представляется возможной без понимания многосложности его природы и осознания многофакторности телевизионной практики и связанных с ней аспектов.

А это требует междисциплинарного подхода к проблеме как с точки зрения искусствоведения, культурологии, эстетики, этики, психологии, семиотики, так и системной методологии, базирующейся на незыблемых законах взаимообусловленности различных слагаемых и векторов развития в единстве, трансформациях и в сочетании с сугубо профессиональными, художественно-творческими проявлениями.

Успешное решение такого рода задачи предполагает критически-оценочный, формально-содержательный, сущностный анализ телепрограмм, выявляющий образно-смысловые значения телевидения как вида искусства. Осмысление же сути информационнокоммуникативных сфер, закономерностей производственно-творческого процесса, в который вовлечены журналисты в том числе, а также событийность, скорость реагирования, доступность, динамичность осуществления скажут в пользу телевидения как СМИ.

Выявление и осмысление производственнотворческих, технологических, методологических аспектов аудиовизуального образа позволяют идентифицировать телевидение и как вид искусства, и как средство массовой информации и коммуникации, и как продукт технического прорыва, помогая определить его место в современном социокультурном пространстве. А структурно-функциональный, объектнопредметный, идейно-содержательный анализ способствует классификации жанров и жанровых разновидностей телевидения, освещению его институциональной, формотворческой деятельности.

T.e. изучение проблемы предполагает системный подход к пониманию природы ТВ как единства и целостности его составляющих с соответствующими социальными, профессиональными, техническими особенностями функционирования и развития.

Сегодня без телевидения, которое буквально «вросло» в повседневность, открывая столь необходимые для жизни коммуникационные модели, не представляется полноценное, социально адаптированное существование человека, нуждающегося в информации и аналитике, художественно-познавательных и развлекательных формах.

Поскольку телевидение живой процесс со своим сложнейшим механизмом взаимодействия различных звеньев, оно постоянно ставит вопросы и нуждается в комплексном охвате и освещении своей деятельности с новых методологических позиций с целью создания объективной картины функционирования в лоне национальной жизни, оптимизации созидательных сфер деятельности. 


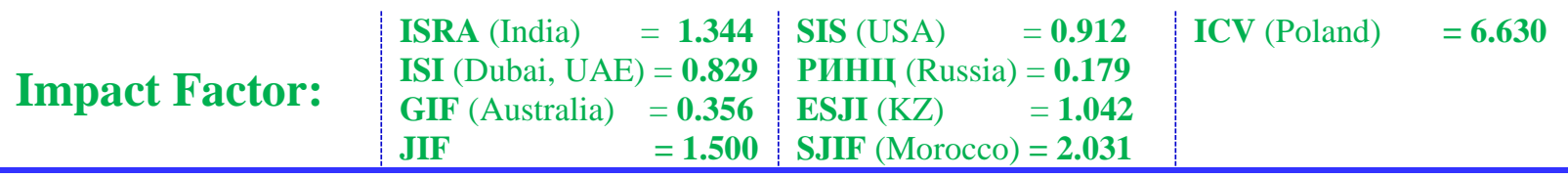

\section{References:}

1. Bagirov E (1978) Ocherki istorii televideniya. Moscow: Iskusstvo, $152 \mathrm{p}$.

2. Baxtin MM (1953) Tvorchestvo Fransua Rable i narodnaya kultura srednevekovya i Renessansa. 2-ye izd. - Moscow: Xudojestvennaya literatura, 1953. - 544 p.

3. Borev VY, Kovalenko AV (1986) Kultura i massovaya kommunikatsiya. - Moscow:Nauka, 1986. - 302 p.

4. Budantsev YP (1995) Sotsiologiya massovoy kommunikatsii: uchebnoye posobiye. Moscow: MNEPU, 1995. - 112 p.

5. Gasparyan V (2000) Tri etapa noveyshey istorii televizionnoy jurnalistiki (1985-1998). Moscow: IPK rabotnikov TV i RV, 2000. - 18 p.

6. Golyadkin N (1996) Kratkiy ocherk stanovleniya i razvitiya otechestvennogo i zarubejnogo televideniya. - Moscow: IPK rabotnikov TV i RV, 1996. - 128 p.

7. Zasurskiy Y (2002) Sredstva massovoy informatsii $\mathrm{v}$ informatsionnom obshestve. Moscow: Aspekt-Press, 2002. - 304 p.

8. Kuznetsov GV, Tsvik VL, Yurovskiy AY (2002) Televizionnaya jurnalistika. - Moscow: Visshaya shkola, 2002. - 304 p.

9. Maklyuen M (1987) Televideniye. Robkiy gigant / TV: vchera, segodnya, zavtra. Moscow: Iskusstvo, 1987. - pp. 7-18.

10. Mixalkovich V (1999) O sushnosti televideniya. - Moscow: VIPK, 1999. - 64 p.
11. Mol A (1973) Sotsiodinamika kulturi /Per. s fr., vstup. st., red. i primech. B.V.Biryukova. Moscow: Progress 1973. - 408 p.

12. Muratov S (2001) Televideniye $\mathrm{v}$ poiskax televideniya. - Moscow: MGU, 2001. - 176 p.

13. Muratov S (2003) Televizionnoye obsheniye v kadre i za kadrom. - Moscow: Aspekt-Press, 2003. - 160 p.

14. Nechay OF (1990) Rakursi: o televizionnix kommunikatsiyax i estetike. - Moscow: Iskusstvo, 1990. - 120 p.

15. Perevalov B (1999) Kulturoformiruyushiye funktsii, sostav, struktura i mesto $\mathrm{v}$ sisteme funktsiy jurnalistiki // Vestnik MGU, Seriya 10Jurnalistika. - Moscow, 1999. - N 5. - pp. 3-21.

16. Proxorov Y (2000) Vvedeniye v teoriyu jurnalistiki. - Moscow: RIP-XOLDING, 2000. 308 p.

17. Razlogov K (288) Iskusstvo ekrana: ot sinematografa do Interneta. - Moscow: ROSSPEN, 2010. - $288 \mathrm{p}$.

18. Sapunov B (1988) Televideniye i kultura. Moscow: Znaniye, 1988. - 48 p.

19. Sokolov A (1997) Priroda ekrannogo tvorchestva. - Moscow: CheRo, 1997. - 272 p.

20. Uilyams R (2003) Televideniye: texnologiya i kulturhaya forma. - London - New-York: Routdlidj Klassiks, 2003. - 172 p.

21. Urazova S (2012) Televideniye kak institutsionalnaya sistema otrajeniya sotsiokulturnix potrebnostey: avtoref. dokt. diss. - Moscow, 2012. - 36 p. 